\title{
Origins and diversity of the Portuguese Landrace of Eucalyptus globulus
}

\author{
Jules S. Freeman ${ }^{\mathrm{a} *}$, Cristina M.P. Marques ${ }^{\mathrm{b}}$, Victor CARocha ${ }^{\mathrm{b}}$, Nuno Borralho ${ }^{\mathrm{b}}$, Brad M. PotTs $^{\mathrm{a}}$, \\ René E. VAILlANCOURT ${ }^{\mathrm{a}}$
}

\author{
${ }^{a}$ School of Plant Science and Cooperative Research Centre for Forestry, University of Tasmania, Private Bag 55, Hobart, Tasmania 7001, Australia \\ ${ }^{\mathrm{b}}$ RAIZ, Centro de Investigacao Florestal, Quinta de S. Francisco Apartado 15, Aveiro, Portugal
}

(Received 21 July 2006; accepted 7 February 2007)

\begin{abstract}
The Portuguese Landrace of Eucalyptus globulus is of unknown origin, with the earliest plantings of this tree species dating back to the early 19th century. In Portugal it is currently a major seed source for plantations and is also used in breeding programs. Eucalyptus globulus is native to south-eastern Australia. The substantial genetic differentiation of chloroplast and nuclear DNA markers between different native geographic races of this species allowed us to uncover the Australian origins of the Portuguese Landrace and to study its genetic diversity. To achieve this, we sequenced a highly polymorphic region of chloroplast DNA from 47 Portuguese Landrace individuals, and genotyped 34 of these using seven nuclear microsatellites. We compared these individuals to those in a database comprising chloroplast DNA sequence profiles from 292 native trees and seven nuclear microsatellites from 372 native trees. The majority of the Portuguese Landrace samples had closest affinities, in both marker systems, to native trees from south-eastern Tasmania, but some had affinities to trees from south-eastern Victoria. The discrepancies in the affinities indicated by chloroplast versus nuclear DNA markers could be explained by inter-race hybridisation after introduction. The genetic diversity in the Portuguese Landrace was less than that found in native E. globulus at the species level, but was similar to the average diversity found in native races of the species. This study demonstrates the power of using independent marker systems to identify the origins and diversity of domesticated populations, by comparison with variation in native stands.
\end{abstract}

geographic origins / diversity / Portuguese Landrace / Eucalyptus globulus / molecular markers

Résumé - Origine et diversité génétique de la race locale portugaise d'Eucalyptus globulus. La race locale portugaise d'Eucalyptus globulus est d'origine inconnue. Les plantations les plus anciennes de cette espèce remontent au début du XIX ${ }^{\mathrm{e}}$ siècle. Au Portugal, il s'agit d'une source majeure pour les plantations actuelles et ce matériel est aussi utilisé dans le cadre des programmes d'amélioration. L'Eucalyptus globulus est originaire du SudEst de l'Australie. La différenciation génétique très forte entre les différentes races géographiques de cette espèce pour des marqueurs ADN nucléaires et chloroplastiques nous permet de révéler les origines australiennes de cette race locale portugaise et d'étudier sa diversité génétique. Pour cela, nous avons séquencé une région très polymorphe de l'ADN chloroplastique à partir de 47 individus de la race locale portugaise et génotypé 34 d'entre eux en utilisant 7 microsatellites nucléaires. Nous avons comparé ces individus à ceux issus d'une base de données comportant le profil des séquences d'ADN chloroplastiques de 292 arbres de l'aire naturelle ainsi que les 7 microsatellites nucléaires de 372 arbres de l'aire naturelle. La majorité des échantillons de la race locale portugaise montre pour les deux types de marqueurs, la plus grande affinité avec les arbres issus du Sud-Est de la Tasmanie, mais quelques-uns montrent une affinité avec des arbres du Sud-Est de Victoria. Les différences observées entre marqueurs chloroplastiques et nucléaires pourraient s'expliquer par une hybridation inter-raciale après introduction de l'espèce. La diversité génétique de la race locale portugaise est plus faible que celle observée au niveau espèce chez E. globulus dans son aire naturelle, mais elle est semblable à la diversité moyenne observée au niveau des races de l'espèce dans son aire naturelle. L'utilisation de marqueurs indépendants est particulièrement pertinente pour identifier les origines et la diversité des populations domestiquées en comparaison avec la variabilité observée au sein de l'aire naturelle.

origine géographique / diversité / race locale / Eucalyptus globulus / marqueurs moléculaires

\section{INTRODUCTION}

Spatially structured genetic variation has been demonstrated in many forest trees with widespread distribution [21,27], reviewed by [24] and genetic material from some regions is usually preferred over others for breeding purposes [29]. Hence, studies into the geographic origins of domesticated forest trees can identify the genetic resources captured during the domestication process and those that remain untapped (e.g. [28, 29]. Additionally, during the domestication process, tree breeders face the challenge of improving specific

* Corresponding author: jsfreema@utas.edu.au commercial traits while maintaining overall genetic diversity [29], making knowledge of the origin and genetic diversity of germplasm used in the domestication of forest trees important for effective management of genetic resources [34,42].

Eucalyptus globulus is widely grown for pulpwood plantations in temperate regions of the world [12,32]. The natural distribution of E. globulus (sensu [5]) is restricted to southeastern Australia, including the island of Tasmania, southern Victoria and the Bass Strait Islands (Fig. 1). However, E. globulus seed was rapidly spread throughout the world in the 19th century and landraces are now established in many countries [9]. The first formal breeding of the species began 

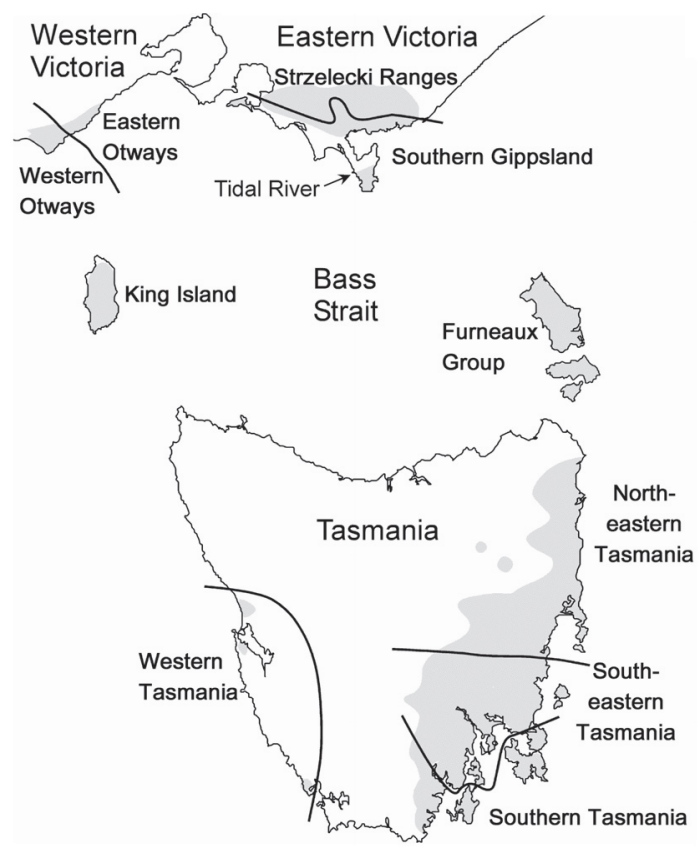

Figure 1. The natural distribution of Eucalyptus globulus and its major races as used in this study. Grey area indicates the natural distribution of the species. Geographical regions are shown in large font, while race names are shown in smaller font, with their boundaries defined by solid lines. (Figure modified from Dutkowski and Potts [11], based on new information from Lopez et al. [22].)

in Portugal in 1966, based on phenotypic selections from local landrace populations [8,32]. Breeding programs for E. globulus have since been established in other countries including Australia, Chile and Spain [12,32]. In many cases the Australian origin of these exotic populations have not been welldocumented and are often complicated by multiple introductions [32]. There is also concern that some of these landraces have originated from a narrow genetic base that could, for example, have contributed to the poor performance of E. globulus in South Africa [12]. In addition, the area of origin within the native gene pool is important as the species is highly variable and germplasm from some areas have greater economic value for pulpwood plantations than others [2,17].

It is believed that E. globulus was first introduced into Portugal in 1829 [9], possibly via southern France, which is thought to have been an important secondary distribution point [40]. Later introductions of genetic material have no doubt taken place but, again, the Australian origin of these introductions is unrecorded. However, it is thought that the original Portuguese Landrace is probably derived from a narrow genetic base, which may have led to inbreeding [12]. Eucalyptus globulus landrace material is now a major component of the breeding and deployment populations in Portugal $[3,7,12,15]$. Such programs usually combine the landrace material with more recently introduced germplasm of known Australian origin (e.g. [3]).

The phenotypic expression of quantitative traits has been used to estimate the population structure and genetic varia- tion in landrace and native populations of E. globulus (e.g. $[1,11,23])$. Such analyses show that considerable spatially structured quantitative genetic variation exists in E. globulus and that the Portuguese Landrace appears to have affinities with the South-eastern Tasmanian race [22,31]. However, many morphological traits are subject to selection, potentially giving an inaccurate picture of the genetic diversity and affinities of a given landrace [20,38]. The advent of selectively neutral molecular markers offers powerful tools to more accurately investigate these issues (e.g. [4, 15]. Strong spatially structured genetic differentiation exists within E. globulus at the molecular level in nuclear $[20,30,38]$ and chloroplast $[13,35]$ DNA markers, providing the basis for determining the natural origin of un-pedigreed trees. Two such markers developed for $E$. globulus are the $\mathrm{J}_{L A+}$ [13] region of chloroplast DNA (cpDNA) and nuclear microsatellites (SSR; [37]). CpDNA is inherited uniparentally and maternally in Eucalyptus $[6,25]$, so will reflect the matrilineal component of an individual's pedigree, while nuclear SSR will reflect the overall genetic composition of an individual because they recombine in each generation. Several studies have investigated the genetic diversity of selections from the E. globulus Portuguese Landrace compared to native material, based upon morphology [1,22] and ISSR markers [15]; however, this study is the first to use cpDNA and nuclear SSR markers in an attempt to find the Australian origins and to compare the amount of genetic diversity in the Portuguese E. globulus landrace with that of native populations of E. globulus.

\section{MATERIALS AND METHODS}

Forty-seven trees were collected from plantations in 29 different localities, throughout the regions where E. globulus is grown in Portugal (Tab. I and Fig. 2). These trees were part of the initial RAIZ plus tree selection program, carried out during the late 1980s. The plantations were established using unimproved genetic material collected and produced in Portugal, hence representing the local landrace. In addition, two trees of know Australian origin were also collected (see blind controls in Tab. I), but the origins of these trees were masked until after the analysis was finished. DNA was extracted by the Doyle and Doyle [10] method as modified by Grattapaglia and Sederoff [16].

The $\mathrm{J}_{L A+}$ region of the chloroplast genome was amplified and sequenced in both the forward and reverse directions, following the methods of Freeman et al. [13], except that sequencing was performed on a CEQ8000 (Beckman Coulter) automated sequencer. Sequences were aligned manually using Sequence Navigator software (ABI PRISM/Perkin-Elmer). Haplotypes were classified by comparing the cpDNA sequence in each of the 47 Portuguese individuals with our extensive database of $\mathrm{J}_{L A+}$ variation, comprising 122 variable characters scored in 292 trees from native populations of $E$. globulus. The database incorporates 225 trees genotyped by Freeman et al. [13], 37 by McKinnon et al. [26] and an additional 30 native trees which were genotyped for this study, including two individuals from the Furneaux group, five from the Otway Ranges and 23 from south-eastern Victoria. The sequence characters were based on those outlined by Freeman et al. [13], with the addition of new characters discovered in E. globulus since that study. Portuguese Landrace individuals with cpDNA sequence identical to trees in the native range 
Table I. Identity of Portuguese Landrace samples, their chloroplast DNA (cpDNA) haplotype and their cpDNA and SSR assignment to various regions of the natural distribution of E. globulus. CpDNA assignment is based on the natural distribution of the clade (Fig. 2) or haplotype (Fig. 3). SSR assignment indicates the native race (see Fig. 1) with the highest and second highest probabilities of assignment, derived from analysis using Structure software [33]. * = Haplotypes endemic to the Portuguese Landrace. OP stands for open pollinated. CG741, and CG863 were "blind controls" from known locations in Australia.

\begin{tabular}{|c|c|c|c|c|}
\hline Identity & $\begin{array}{l}\text { Locality } \\
\text { (or pedigree) }\end{array}$ & $\begin{array}{l}\text { CpDNA } \\
\text { haplotype }\end{array}$ & $\begin{array}{l}\text { CpDNA } \\
\text { assignment }\end{array}$ & SSR assignment (prob \%) \\
\hline Portuguese & Landrace & & & \\
\hline VF18 & Azambuja & $\mathrm{Cc} 41$ & Tas (incl. King Is.) & SE Tas (64): W Tas (17) \\
\hline TB43 & Rio Maior & $\mathrm{Cc} 41$ & Tas (incl. King Is.) & NE Tas (71): S Tas (17) \\
\hline LP32 & Castelo Paiva & $\mathrm{Cc} 41$ & Tas (incl. King Is.) & SE Tas (54): NE Tas (14) \\
\hline PL133 & Povoa do Lanhoso & $\mathrm{Cc} 41$ & Tas (incl. King Is.) & SE Tas (72): S Tas (15) \\
\hline CT47 & Coruche & Cc56 & SE Tas & SE Tas (90): Tidal River (2) \\
\hline LB250 & Serra Monchique & Cc56 & SE Tas & SE Tas (94): W Tas (1) \\
\hline CN5 & Abrantes & $\operatorname{Cc56}$ & SE Tas & SE Tas (89): S Tas (3) \\
\hline AF12 & Arouca & $\operatorname{Cc56}$ & SE Tas & \\
\hline CA19 & Mesao Frio & $\operatorname{Cc56}$ & SE Tas & SE Tas (80): S Tas (4) \\
\hline AL12 & Nisa & Cc56 & SE Tas & \\
\hline EST7 & Ponte Lima & $\operatorname{Cc} 56$ & SE Tas & \\
\hline SN10 & Sanguinhal & $\operatorname{Cc56}$ & SE Tas & \\
\hline AL10 & Nisa & $\operatorname{Cc56}$ & SE Tas & SE Tas (89): S Tas (3) \\
\hline PL30 & Constancia & Cc56 & SE Tas & SE Tas (94): NE + W Tas (1) \\
\hline RE25 & Santa Tirso & $\mathrm{Cc} 70 *$ & Widespread & SE Tas (83): S Tas (10) \\
\hline CN32 & Abrantes & $\mathrm{Cg} 33$ & Gippsland & \\
\hline FV19 & Barcelos & $\mathrm{Cg} 33$ & Gippsland & SE Tas (77): Strzelecki (6) \\
\hline LB244 & Monchique & $\mathrm{Cg} 33$ & Gippsland & Tidal River (29): KI (21) \\
\hline SMC3 & Barcelos & $\mathrm{Cg} 33$ & Gippsland & Furneaux (30): SE Tas (25) \\
\hline SPR7 & Lousada & $\mathrm{Cg} 33$ & Gippsland & \\
\hline AV6 & Castelo Branco & $\mathrm{Cg} 33$ & Gippsland & King Is. (50): SE Tas (17) \\
\hline ME70 & Penamacor & $\mathrm{Cg} 33$ & Gippsland & SE Tas (42): Gippsland (21) \\
\hline JG2 & Santo Tirso & $\mathrm{Cg} 33$ & Gippsland & \\
\hline VC9 & Valongo & $\mathrm{Cg} 33$ & Gippsland & SE Tas (71): Tidal River (9) \\
\hline FC22 & Geres Evora & S4 & SE Tas & \\
\hline $\mathrm{CC} 4$ & Nisa & S43 & SE Tas & SE Tas (76): S Tas (9) \\
\hline $\mathrm{PC} 10$ & Paredes de Coura & S43 & SE Tas & \\
\hline RE42 & Santo Tirso & S43 & SE Tas & SE Tas (95): S Tas (1) \\
\hline MN43 & Montemor Novo & S43 & SE Tas & SE Tas (95): S Tas (1) \\
\hline QG15 & Constancia & S43 & SE Tas & NE Tas (75): S Tas (7) \\
\hline MP11 & Penamacor & S43 & SE Tas & NE Tas (42): S Tas (17) \\
\hline MN35 & Vendas Novas & S43 & SE Tas & SE Tas (91): S Tas (1) \\
\hline ST51 & Santo Tirso & $\mathrm{S} 68 *$ & SE Tas & SE Tas (81): NE Tas (4) \\
\hline MB238 & Bracal & $\mathrm{S} 69 *$ & SE Tas & \\
\hline CM7 & Celourico & S69 * & SE Tas & \\
\hline AM7 & Arouca & $\mathrm{S} 70 *$ & SE Tas & SE Tas (36): KI (22) \\
\hline $\mathrm{TC} 1$ & Celourico & $\mathrm{S} 70 *$ & SE Tas & SE Tas (63): S Tas (23) \\
\hline CR54 & Chamusca & $\mathrm{S} 70 *$ & SE Tas & \\
\hline AJ1 & Azambuja & $\mathrm{S} 70 *$ & SE Tas & \\
\hline CN44 & Abrantes & S104 * & SE Tas & SE Tas (65): E Otways (15) \\
\hline $\mathrm{BN} 22$ & Ferreira Zezere & S105* & SE Tas & SE Tas (70): S Tas (7) \\
\hline CCD2 & Nisa & S106* & SE Tas & SE Tas (54): KI (19) \\
\hline PL139 & Constancia & S107* & SE Tas & King Isld (51): SE Tas (33) \\
\hline $\mathrm{CH} 3$ & Amarante & $\mathrm{S} 110 *$ & SE Tas & SE Tas (76): Furneaux (11) \\
\hline VZ3 & Nisa & $\mathrm{S} 110 *$ & SE Tas & SE Tas (32): NE Tas (19) \\
\hline Q7 & Not given & $\mathrm{S} 111 *$ & SE Tas & W. Otways (47): W Tas (14) \\
\hline MN303 & Vendas Novas & $\mathrm{S} 112 *$ & SE Tas & SE Tas (54): Furneaux (14) \\
\hline \multicolumn{5}{|l|}{ Blind controls } \\
\hline CG863 & From OP seed collected on Furneaux & $\mathrm{Cg} 39 *$ & Gippsland or Furneaux & Furneaux (76): Tidal River (7) \\
\hline CG741 & From OP seed collected on Furneaux & $\mathrm{Cg} 43 *$ & Gippsland or Furneaux & Furneaux (80): SE Tas (9) \\
\hline
\end{tabular}




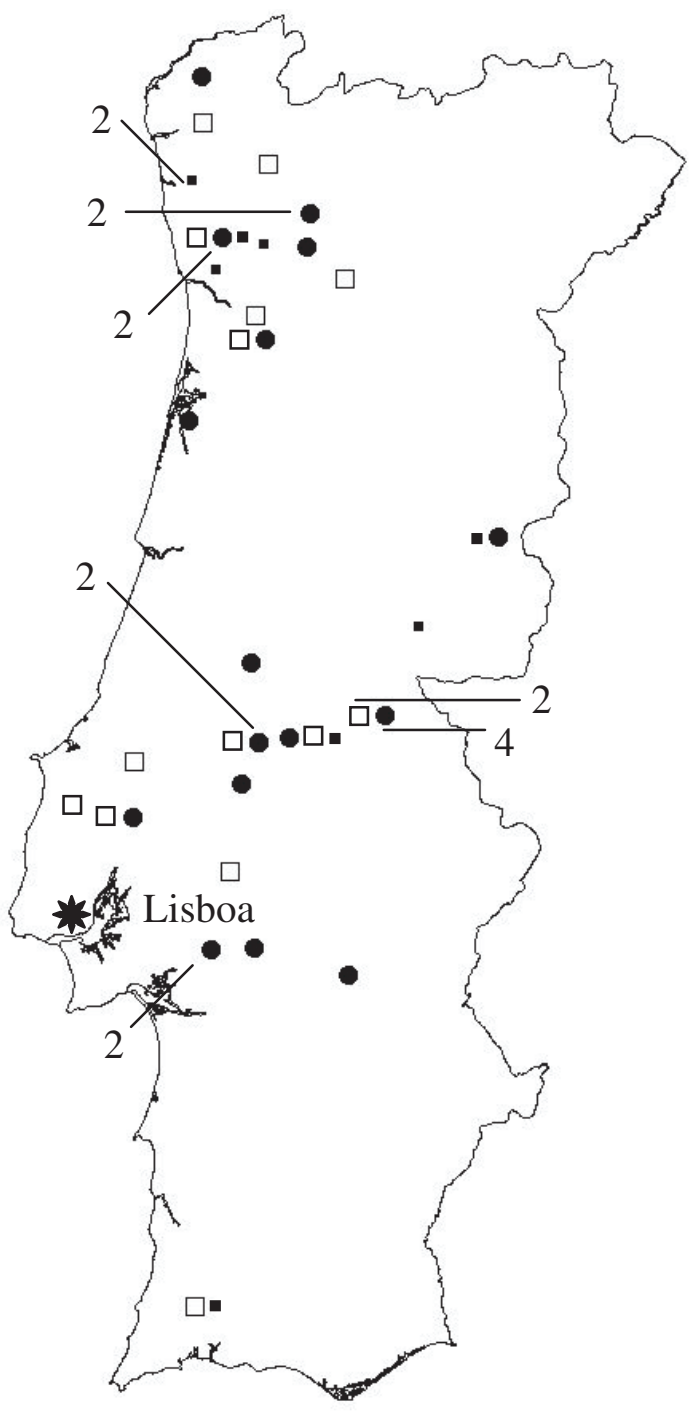

Figure 2. Map of Portugal, showing the localities where samples were taken and the distribution of the major chloroplast DNA clades and groups of haplotypes in Portugal. Numbers indicate the number of trees at localities with multiple samples. See Figure 3 for key to symbols.

were identified as possessing the same haplotype. CpDNA sequence affinities were used to assign haplotypes to clades that have been defined by phylogenetic analysis [13,26].

Thirty-four Portuguese Landrace individuals were fingerprinted using nuclear SSR. PCRs for SSR amplification used a total volume of $10 \mu \mathrm{l}$, containing $20 \mathrm{ng}$ DNA, PCR buffer $(67 \mathrm{mM}$ Tris- $\mathrm{HCl}$, $\mathrm{pH} 8.8,16.6 \mathrm{mM}\left(\mathrm{NH}_{4}\right)_{2} \mathrm{SO}_{4}, 0.45 \%$ Triton $\mathrm{X}-100,0.2 \mathrm{mg} / \mathrm{mL}$ gelatine), $200 \mu \mathrm{M}$ dNTPs, $2 \mathrm{mM} \mathrm{MgCl}_{2}, 5 \%$ dimethyl sulphoxide (DMSO), $100 \mathrm{nM}$ of each forward and reverse primer (EMCRC 1a, $3,7,11$ ) or $150 \mathrm{nM}$ of each forward and reverse primer (EMCRC 2, 10, 12), 0.5 U Taq polymerase. Sterile distilled water was added to achieve $10 \mu \mathrm{L}$ final volume. PCR conditions (using a PTC-100, MJ Research, Inc. or Eppendorf Master Cycler Gradient, Eppendorf ${ }^{\circledR}$ ) were: denaturation at $94{ }^{\circ} \mathrm{C}$ for $30 \mathrm{~s} ; 15$ cycles of denaturation at $94{ }^{\circ} \mathrm{C}$ for $30 \mathrm{~s}$, annealing (at $56^{\circ} \mathrm{C}$ decreasing by $0.2^{\circ} \mathrm{C}$ each cycle) for $30 \mathrm{~s}$, and extension at $72{ }^{\circ} \mathrm{C}$ for $45 \mathrm{~s}$. Followed by 20 cycles with conditions as above, except annealing at $53{ }^{\circ} \mathrm{C}$ and a final extension step at $72{ }^{\circ} \mathrm{C}$ for $7 \mathrm{~min}$. A LI-COR 4200 sequencer was used to separate microsatellite alleles, using 6\% acrylamide gels with L4000-448 as a size standard; electrophoretic output was recorded and alleles were sized using RFLPscan software (Scanalytics).

In order to assign the Portuguese Landrace individuals to native races of E. globulus (as defined by Steane et al. [38]; Fig. 1), the allele composition at 7 SSR loci in the Portuguese Landrace individuals was compared to that from 372 native trees representing 11 quantitative races (Eastern Otways, Western Otways, Southern Gippsland, Strzelecki Ranges, Furneaux Group, North-eastern Tasmania, Southeastern Tasmania, Southern Tasmania, Western Tasmania and King Island; [38]) and Tidal River in Wilsons Promontory National Park, (Steane et al. unpubl. data) using the software Structure[33]. Structure employs a Bayesian clustering method to assign multi-locus genotypes of individuals to specific populations on the basis of allele frequencies estimated for each pre-defined population (i.e. native race). In order to assign individuals to races, a model was used that incorporated admixture and independent allele frequencies between populations. A burn-in of 100000 iterations was followed by a run length of 100000 iterations. Portuguese Landrace individuals were allocated to native races based on their probability of assignment from Structure. POPGENE (Version 1.31; [39]) software was used to calculate the observed $\left(N_{\mathrm{a}}\right)$ and effective $\left(N_{\mathrm{e}}\right)$ number of alleles, as well as the observed and expected heterozygosities $\left(H_{\mathrm{o}}\right.$ and $\left.H_{\mathrm{e}}\right)$ for the Portuguese Landrace sample, allowing comparison of these parameters with those obtained for the total native population, the mean of all the races, or the individual races.

\section{RESULTS}

\subsection{Chloroplast DNA}

All 47 Portuguese Landrace samples belonged to either of the two major clades found in native E. globulus, designated central (C; 24 samples) and southern $(\mathrm{S} ; 23$ samples) after their natural distribution (Fig. 3 and Tab. II). The Portuguese Landrace collection was quite diverse at the haplotype level, with 16 haplotypes present in the 47 Portuguese Landrace samples for which complete $\mathrm{J}_{L A+}$ sequence was obtained. Despite the evident haplotype diversity, haplotype sharing was common, with 30 individuals represented by 4 common haplotypes (Cc41, Cc56, Cg33, S43). Eleven of the 16 haplotypes (one C and ten $\mathrm{S}$ ) were unique to the Portuguese Landrace, while the remaining five (Cc41, Cc56, Cg33, S4, S43) have been found in natural stands. Within the major clades found in the Portuguese Landrace, a greater haplotype diversity $(d=$ number of haplotypes/number of individuals) was evident in the $\mathrm{S}$ clade $(0.52)$ than the Cclade (0.17). Native trees from throughout the natural distribution of E. globulus have similar haplotype diversity within the $S$ clade (0.52), but have more diversity within the Cclade (0.33). Within the Central clade, the Cc group was more common (15 individuals) than the Cg group (nine individuals) in the Portuguese Landrace, which was also the case in the native trees. However, only three different Cc haplotypes were detected compared to one Cg haplotype, clearly indicating reduced genetic diversity in the $\mathrm{Cg}$ group in 

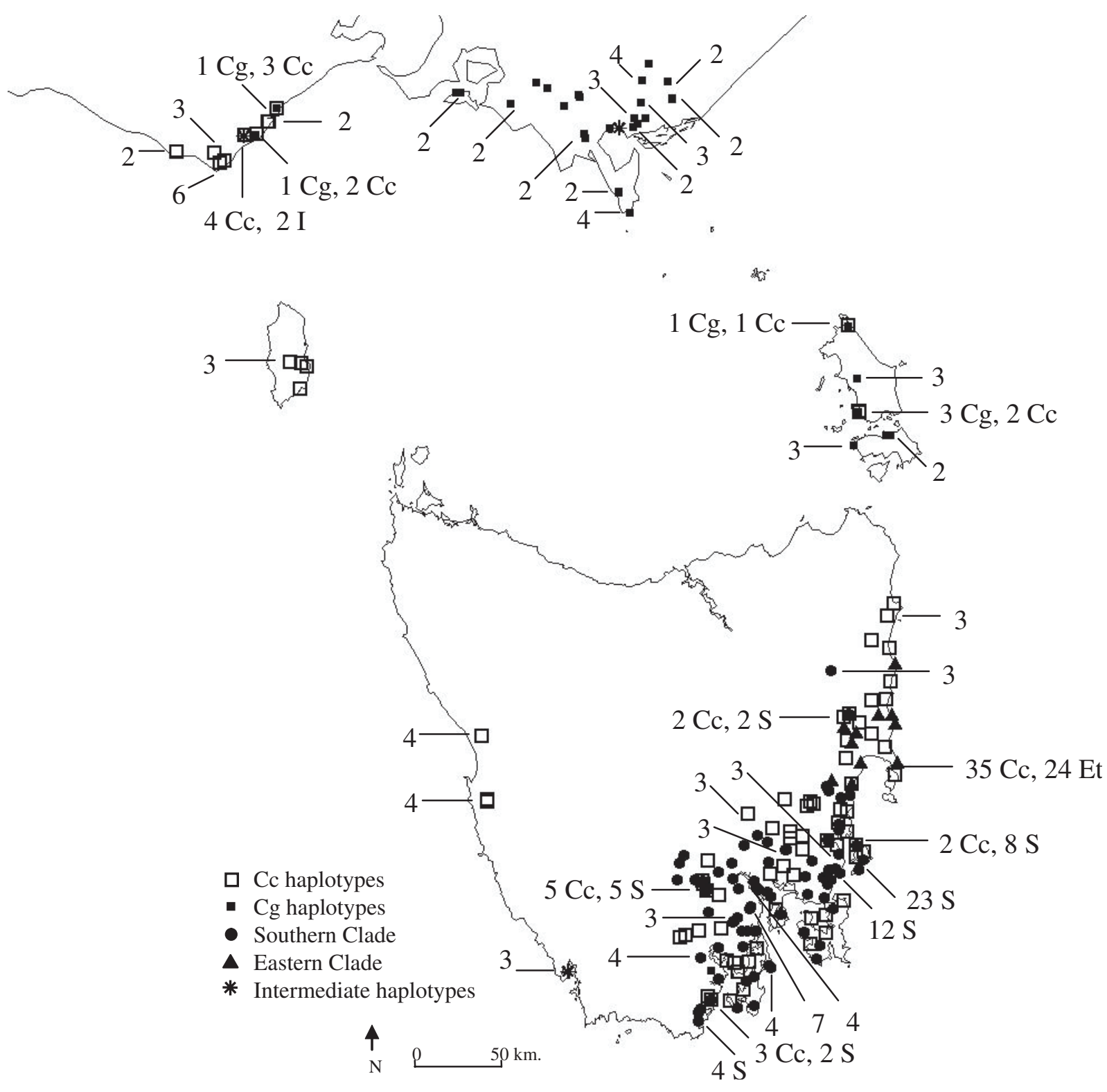

Figure 3. Broad-scale distribution of the major chloroplast DNA clades and groups of haplotypes across the native distribution of Eucalyptus globulus in south-eastern Australia. Both the $\mathrm{Cc}$ and $\mathrm{Cg}$ haplotypes belong to the Central clade. Numbers indicate the number of trees at localities with multiple samples.

the Portuguese Landrace $(d=0.11)$ compared to the native gene pool $(d=0.36$; Tab. II $)$.

Thirty-one of the 47 Portuguese Landrace individuals possessed haplotypes previously found in the native population of E. globulus (Tab. I). The majority (26/31) of individuals with known cpDNA haplotypes in the Portuguese Landrace had haplotypes that in our database were restricted to two broad regions of the natural range of E. globulus, south-eastern Tasmania (Cc56, S4, and S43; Fig. 4) and south-eastern Victoria (Cg33; Fig. 4). The disproportionate representation of the $\mathrm{S}$ clade in the Portuguese Landrace (49\% of samples) compared to that in the native range (37\%) is evidence for a substantial south-eastern Tasmanian contribution to the Portuguese Lan- drace, since the $\mathrm{S}$ haplotypes have been found only in Tasmania and most come from the south-east (Fig. 3). Clear affinities of some Portuguese Landrace samples to south-eastern Victoria (including Gippsland and the foothills of the Strzelecki Ranges) are suggested by the common occurrence of haplotype Cg33 (nine Portuguese Landrace individuals), which is widespread in this region and has not been found elsewhere to date (Fig. 4). Haplotype Cc41, found in four Portuguese Landrace samples, predominantly occurs in south-eastern Tasmania, but has also been found on King Island (Fig. 4). No clear spatial pattern was evident in the cpDNA haplotype or clade distribution in the 29 different localities sampled within Portugal (Fig. 2). Similarly, most Portuguese localities with 
Table II. The number of haplotypes and samples assigned to each major clade or haplotype group of Eucalyptus globulus, in the native range and in the Portuguese Landrace.

\begin{tabular}{|c|c|c|c|c|c|c|c|c|c|}
\hline \multirow[b]{2}{*}{$\begin{array}{l}\text { Clade } \\
\text { or haplotype group }\end{array}$} & \multirow[b]{2}{*}{ Natural distribution } & \multicolumn{4}{|c|}{ Native range } & \multicolumn{4}{|c|}{ Portuguese Landrace } \\
\hline & & $\begin{array}{l}\text { No. of } \\
\text { haplotypes }\end{array}$ & $\begin{array}{l}\text { No. of } \\
\text { samples }\end{array}$ & $\mathrm{d}^{\mathrm{a}}$ & $\begin{array}{l}\% \text { of } \\
\text { samples }\end{array}$ & $\begin{array}{l}\text { No. of } \\
\text { haplotypes }\end{array}$ & $\begin{array}{l}\text { No. of } \\
\text { samples }\end{array}$ & $\mathrm{d}^{\mathrm{a}}$ & $\begin{array}{l}\% \text { of } \\
\text { samples }\end{array}$ \\
\hline Central (Cc) & $\begin{array}{l}\text { Widespread, but infrequent in } \\
\text { Furneaux Group and not found } \\
\text { in south-eastern Victoria }\end{array}$ & 34 & 108 & 0.31 & 37 & 3 & 15 & 0.20 & 32 \\
\hline Central (Cg) & $\begin{array}{l}\text { Not in Tasmania or King Island, } \\
\text { most frequent in Furneaux } \\
\text { Group and south-eastern Victoria }\end{array}$ & 21 & 58 & 0.36 & 20 & 1 & 9 & 0.11 & 19 \\
\hline Eastern (Et) & Only north-eastern Tasmania & 6 & 12 & 0.50 & 4 & 0 & & & \\
\hline Intermediate (I) & Rare over whole range & 2 & 2 & 1.00 & 1 & 0 & & & \\
\hline Western $(\mathrm{W})$ & Only in south-western Tasmania & 1 & 3 & 0.33 & 1 & 0 & & & \\
\hline Totals & & 122 & 292 & 0.42 & & 16 & 47 & 0.34 & \\
\hline
\end{tabular}

${ }^{a}$ Number of haplotypes per sample for each clade or group.

multiple trees sampled featured a mix of the major cpDNA clades or groups in E. globulus.

\subsection{Nuclear DNA}

Variation at seven SSR loci was examined in 34 individuals of the Portuguese Landrace. This collection of the Portuguese Landrace was highly polymorphic, with a mean of 9.7 alleles per locus. However, the mean effective number of alleles per locus $\left(\mathrm{N}_{\mathrm{e}}=4.8\right)$ was close to half the observed number of alleles per locus, indicating the presence of numerous rare alleles in the Portuguese Landrace. The high number of alleles was reflected in the high observed and expected heterozygosity $\left(\mathrm{H}_{\mathrm{o}}=0.62\right.$ and $\mathrm{H}_{\mathrm{e}}=0.75$, respectively).

The substantial geographic structuring of genetic variation in native $E$. globulus, allowed individuals to be readily assigned to native races by their allele frequencies at $7 \mathrm{SSR}$ loci. Analysis of these SSR data using Structure suggested that the majority (26/34) of the Portuguese Landrace individuals have their closest affinities to the South-eastern Tasmanian race (Tab. I). Other Portuguese Landrace individuals (3/34) had closest SSR affinities to the North-eastern Tasmanian race, King Island (2/34), the Furneaux Islands, the Otway region of Western Victoria and Tidal River in the south-east of Victoria (one individual each; Tab. II).

In most cases, the SSR data confirmed the affinities suggested by cpDNA, in some instances, with a greater resolution. For example, those bearing haplotypes $\mathrm{Cc} 41$, which is found in both King Island and south-eastern Tasmania, all had closest SSR affinities to south-eastern Tasmania (Tab. I). In agreement with the cpDNA data, the Portuguese Landrace had SSR affinities to eastern Tasmania in the bulk (15/17) of the trees (with SSR data available) bearing the S haplotype (13 South-eastern Tasmania, 2 North-eastern Tasmania) and all individuals bearing haplotypes Cc41 and Cc56 (9 Southeastern Tasmania, 1 North-eastern Tasmania). However, for seven individuals there was a clear discrepancy between the affinities suggested by SSR and cpDNA (Tab. II). The major- ity of these discrepancies arose in individuals bearing $\mathrm{C}$ haplotypes (particularly $\mathrm{Cg}$ ), with cpDNA affinities to mainland Australia, but SSR affinities to south-eastern Tasmania.

\section{DISCUSSION}

\subsection{Origins of the Portuguese Landrace}

Despite differences between nuclear and chloroplast DNA markers in modes of inheritance and genetic architecture in the native stand, the SSR affinities of the Portuguese Landrace individuals were largely congruent with the cpDNA evidence. The two blind controls demonstrated the power of combining SSR and cpDNA analysis by independently identifying the same area of origin (Tab. I). The similar affinities suggested by the two independent marker systems provide strong evidence that the Portuguese Landrace individuals sampled were predominantly derived from two broad regions, south-eastern Tasmania and to a lesser extent south-eastern Victoria.

The Otway region of western Victoria and King Island remain as possible, but not likely, areas of origin for some Portuguese Landrace individuals. However, in all three cases where these regions are suggested there is disagreement between the origin inferred from cpDNA and SSR markers. For example, two individuals (AV6 and PL139) have their closest SSR affinities to King Island and one (Q7) to the Otways. However, in each case the probabilities of assignment are all close to $50 \%$, well below the mean for this study $(65.5 \%)$, with a substantial contribution from the race with the second highest probability of assignment, which in each case was from Tasmania (see Tab. I). Such probabilistic assignment to multiple groups using Structure software has been used to infer admixture (hybridisation) between differentiated groups in trout [19], sunflower [18] and between teosinte and maize [14]. The three Portuguese Landrace samples (AV6, PL139 and Q7) for which the SSR data suggests a substantial contribution of two different races (representing Tasmania and mainland Australia) are also likely to represent hybridisation between trees 

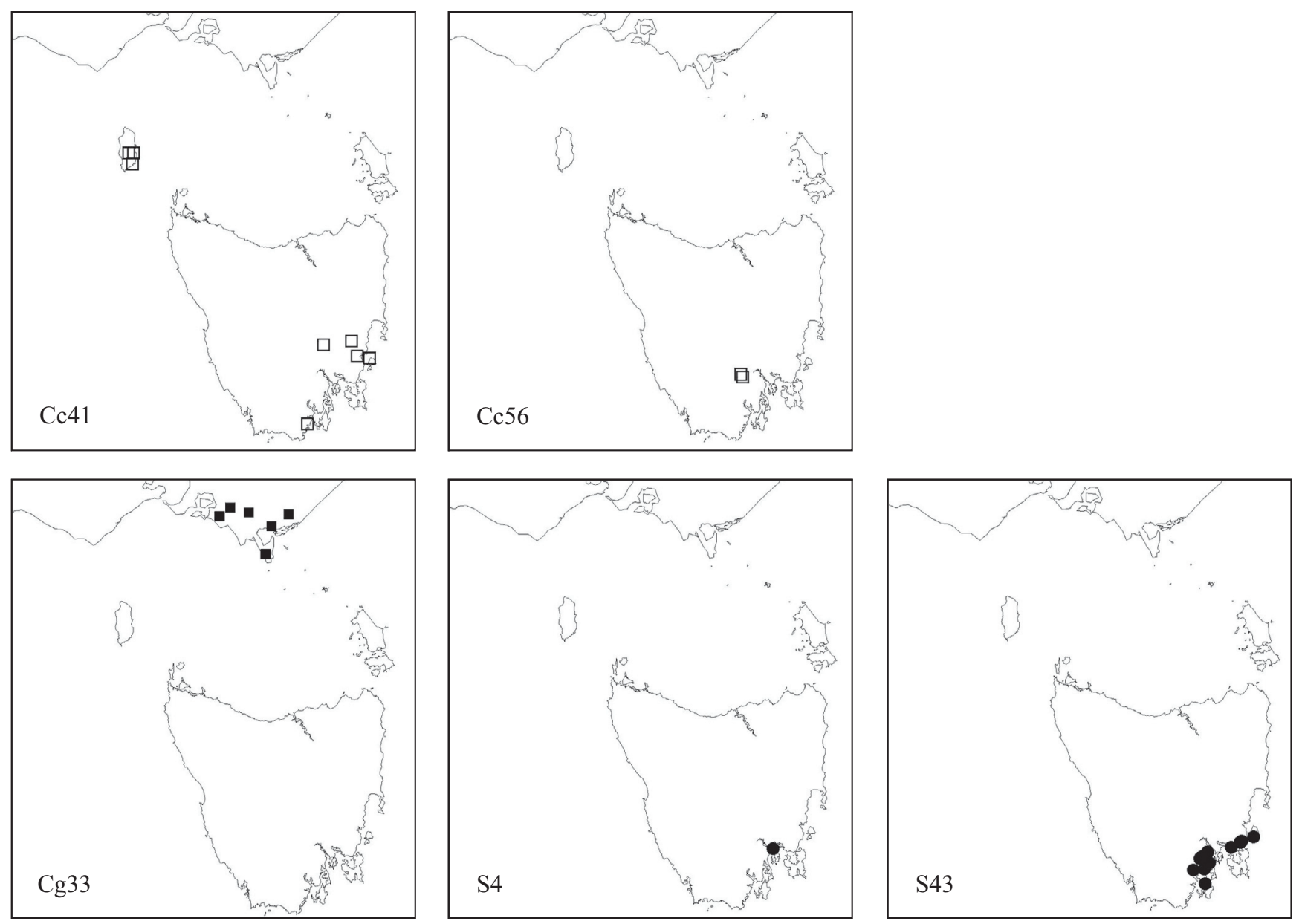

Figure 4. The native Australian distribution of individual haplotypes found in the Portuguese Landrace of Eucalyptus globulus.

originating from different races. Similarly, in other trees the assignment probability suggests a substantial contribution of two different races (e.g. AM7 and SMC3; Tab. I) and this is likely to be indicative of hybridisation.

Despite the general agreement about origins suggested by cpDNA and SSR, some obvious discrepancies exist between the data sets. Hybridisation between trees originating from different native races since their introduction to Portugal could account for the observed cytonuclear discordance, because progeny of such events would have the maternal cpDNA genotype, but a nuclear genotype reflecting the contribution of each parent (see [36]). In most cases the discrepancy arose where an individual with a cpDNA haplotype characteristic of mainland Australia has closest SSR affinities to South-east Tasmania. This result is consistent with the introgressive displacement of the nuclear genome of minor races by the most common native race represented in the Portuguese Landrace (South-eastern Tasmania). This would be likely to occur where seed is derived from open pollination of trees with a mainland Australian maternal ancestry, due to pollen swamping by the most common (South-east Tasmanian) race. The co-occurrence of trees with haplotypes from south-eastern Tasmania and mainland Australia in numerous locations in Portugal (Fig. 2) is consistent with this hypothesis, since it shows that hybridisation between trees originating from various native races is possible.

Hybridisation between Portuguese Landrace trees originating from different native races of $E$. globulus will make identification of the native origin difficult on the basis of quantitative traits or nuclear markers alone. However, in agreement with the origins suggested in this study, a predominantly southern or south-eastern Tasmanian origin of E. globulus plantations in Portugal was suggested by Orme [31] based on morphological observations, while Lopez et al. [22] found that the closest quantitative genetic affinities of the Portuguese Landrace were to southern Tasmania. A southern Tasmanian origin was also suggested by morphological [31] and molecular [4] affinities for the Spanish E. globulus Landrace, as well as quantitative genetic affinities of landrace material from southern China [41] and Chile [22]. These findings are consistent with southern Tasmania being an early source of seed that was distributed around the world.

\subsection{Genetic diversity of the Portuguese Landrace}

While less than native E. globulus (122 haplotypes in 292 samples, $d=0.42$ ), the cpDNA diversity in the Portuguese 
Landrace was substantial (16 haplotypes among 47 samples, $d=0.34$ ). Assuming that the cpDNA haplotypes of the Portuguese samples have undergone few mutations since the original collection(s) was(were) made in Australia, the discovery of 16 haplotypes means that a minimum of 16 Australian trees is likely to have formed the basis of the Portuguese Landrace. However, it is quite possible that more trees were originally sampled since, in native stands, trees in close proximity may possess the same $\mathrm{J}_{L A+}$ haplotype [26]. The fact that many of the Portuguese localities from which multiple individuals were sampled featured a mix of the major clades and haplotypes within E. globulus suggests that Portuguese plantations are likely to be genetically diverse, even though only two major regions of the native distribution are represented.

The measures of SSR genetic diversity in this sample of the Portuguese Landrace are comparable to those found within single races of E. globulus [38]. Although there was a high number of alleles per locus $\left(\mathrm{N}_{\mathrm{a}}=9.7\right)$, a reduction in the effective number of alleles per locus $\left(\mathrm{N}_{\mathrm{e}}=4.8\right)$ was evident, indicating the presence of numerous rare alleles, as is the case in the natural population (mean per race $\mathrm{N}_{\mathrm{a}}=9.5, \mathrm{~N}_{\mathrm{e}}=4.9$; [38]). However, both $\mathrm{N}_{\mathrm{a}}$ and $\mathrm{N}_{\mathrm{e}}$ were lower in the Portuguese Landrace than across the entire species $\left(\mathrm{N}_{\mathrm{a}}=19.4, \mathrm{~N}_{\mathrm{e}}=6.06\right.$; [38]). The observed and expected heterozygosities in this sample of the Portuguese Landrace $\left(\mathrm{H}_{\mathrm{o}}=0.62, \mathrm{H}_{\mathrm{e}}=0.75\right)$ were very similar to those found in single races of $E$. globulus (mean diversity from 10 races encompassing the natural range of $E$. globulus, $\mathrm{H}_{\mathrm{o}}=0.65, \mathrm{H}_{\mathrm{e}}=0.75$; [38]), but the expected heterozygosity in the Portuguese Landrace was lower than the overall expected heterozygosity in the species $\left(\mathrm{H}_{\mathrm{e}}=0.82\right.$; [38]).

The finding of significant genetic diversity within the Portuguese Landrace is supported by quantitative genetic evidence that different provenances from the Portuguese Landrace appear to be as variable as a selection of 12 native provenances [31] when assessing growth, wood density and frost tolerance [1]. Gemas et al. [15], also found acceptable genetic diversity in selections from the Portuguese Landrace versus native stand material using ISSR markers. The aforementioned hybridisation between trees originating from different native races may have increased heterozygosity in the Portuguese Landrace and, in combination with natural and artificial selection, contributed to genetic differentiation since introduction. This suggestion is supported by observations of differentiation in quantitative traits such as frost tolerance [1] and form [22].

\section{CONCLUSIONS}

Molecular profiles of the Portuguese E. globulus Landrace suggest that south-eastern Tasmania and, to a lesser extent, south-eastern Victoria were very likely original collection points. Although we argue against other potential areas of origin (e.g. King Island and the Otway Ranges), suggested by some of the molecular data, it remains a possibility that these regions had a minor contribution to the Portuguese Landrace. The relatively high level of genetic diversity (in cpDNA sequence and nuclear SSR) found in the Portuguese Landrace, and the fact that original collections appear to have been taken from at least two widely separated locations in the native range, are not consistent with previous suggestions that the Portuguese Landrace may have been derived from a very narrow original collection. However, the molecular evidence suggests the Portuguese Landrace is dominated by genetic material from south-eastern Tasmania, consistent with evidence from quantitative and morphological data. Recently, selections for pulpwood breeding objectives derived from E. globulus base populations have favoured germplasm from races such as the Strzelecki Ranges, Otways and Furneaux [4, 17], which appear to be under represented in the Portuguese Landrace.

Acknowledgements: This research was supported under the Australian Research Council's Discovery funding scheme (project number DP0557260) and the Cooperative Research Centre for Sustainable Production Forestry. We would like to thank Fatima Cunha, Gay McKinnon, Rebecca Jones, Tim Jones and Dorothy Steane for their invaluable assistance with this project.

\section{REFERENCES}

[1] Almeida M.H., Pereira H., Miranda I., Tomé M., Provenance trials of Eucalyptus globulus Labill. in Portugal, in: Potts B.M., Borralho N.M.G., Reid J.B., Cromer R.N., Tibbits W.N., Raymond C.A. (Eds.), Eucalypt plantations: Improving fibre yield and quality, Proceedings CRC-IUFRO Conference, Hobart, 19-24 February 1995, pp. 195-198.

[2] Apiolaza L.A., Raymond C.A., Yeo B.J., Genetic variation of physical and chemical wood properties of Eucalyptus globulus, Silvae Genet. 54 (2005) 160-166.

[3] Araújo J.A., Lemos L., Ramos A., Ferreira J.G., Borralho N.M.G., The RAIZ Eucalyptus globulus breeding program: A BLUP rollingfront strategy with a mixed clonal and seedling deployment scheme, Proceedings IUFRO Conference on silviculture and Improvements of Eucalypts, Salvador, Brazil, (1997) pp. 371-376.

[4] Astorga R., Soria F., Bascuro F., Toval G., Diversity analysis and genetic structure of Eucalyptus globulus Labill. in: Barralho N.M.G., Pereira J.S., Marques C., Coutinho J., Madeira M., Tomë M. (Eds.), Eucalyptus in a changing world, Proceedings IUFRO Conference, Aveiro, Portugal, 11-15 October 2004.

[5] Brooker M.I.H., A new classification of the genus Eucalyptus L'Her. (Myrtaceae), Aust. Syst. Bot. 13 (2000) 79-184.

[6] Byrne M., Moran G.F., Tibbits W.N., Restriction map and maternal inheritance of chloroplast DNA in Eucalyptus nitens, J. Hered. 84 (1993) 218-220.

[7] Costa e Silva J., Dutkowski G.W., Borralho N.M.G., Across-site heterogeneity of genetic and environmental variances in the genetic evaluation of Eucalyptus globulus trials for height growth, Ann. For. Sci. 62 (2005) 183-191.

[8] Dillner B., Ljunger A., Herud O.A., Thune-Larson E., The breeding of Eucalyptus globulus on the basis of wood density, chemical composition and growth rate, Timber Bull. Eur. 23 (1971) 120-151.

[9] Doughty R.W., The Eucalyptus. A natural and commercial history of the gum tree, The Johns Hopkins University Press, Baltimore and London, 2000.

[10] Doyle J.J., Doyle J.L., Isolation of plant DNA from fresh tissue, Focus 12 (1990) 13-15.

[11] Dutkowski G.W., Potts B.M., Geographic patterns of genetic variation in Eucalyptus globulus ssp. globulus and a revised racial classification, Aust. J. Bot. 47 (1999) 237-263. 
[12] Eldridge K., Davidson J., Harwood C., Van Wyk G., Eucalypt domestication and breeding, Oxford University Press, New York, 1993.

[13] Freeman J., Jackson H.D., Steane D.A., McKinnon G.E., Dutkowski G.W., Potts B.M., Vaillancourt R.E., Chloroplast DNA phylogeography of Eucalyptus globulus, Aust. J. Bot. 49 (2001) 831-835.

[14] Fukunaga K., Hill J., Vigouroux Y., Matsuoka Y., Jesus Sanchez Y., Liu K., Buckler E.S., Doebley J., Genetic diversity and population structure of teosinte, Genetics 169 (2005) 2241-2254.

[15] Gemas V.J.V., Neves L.O., Araújo C., Fevereiro P., How can ISSR markers be useful in the management of genetic resources in a Eucalyptus globulus ssp. globulus baseline collection, in: Barralho N.M.G., Pereira J.S., Marques C., Coutinho J., Madeira M., Tomë M. (Eds.), Eucalyptus in a changing world, Proceedings IUFRO Conference, Aveiro, Portugal, 11-15 October 2004.

[16] Grattapaglia D., Sederoff R., Genetic linkage maps of Eucalyptus grandis and Eucalyptus urophylla using a pseudo-testcross mapping strategy and RAPD markers, Genetics 137 (1994) 1121-1137.

[17] Griffin A.R., Deployment decisions-capturing the benefits of tree improvement with clones and seedlings, in: Barros S. (Ed.) Developing the eucalypt of the future, Proceedings IUFRO international symposium, Valdivia, Chile 2001.

[18] Harter A.V., Gardner K.A., Falush D., Lentz D.L., Bye R.A., Rieseburg L.H., Origin of extant domesticated sunflowers in eastern North America, Nature 430 (2004) 210-205.

[19] Hansen M.H., Nielson E.E., Bekkevold D., Mensburg K.D., Admixture analysis and stoking impact assessment in brown trout (Salmo trutta), estimated with incomplete baseline data, Can. J. Fish. Aquat. Sci. 58 (2001) 1853-1860.

[20] Jones R.C., Steane D.A., Potts B.M., Vaillancourt R.E., Microsatellite and morphological analysis of Eucalyptus globulus populations, Can. J. For. Res. 32 (2002) 59-66.

[21] Leonardi S., Menozzi P., Spatial structure of genetic variability in natural stands of Fagus sylvatica L. (beech) in Italy, Heredity 77 (1996) 359-368.

[22] Lopez G.A., Potts B.M., Dutkowski G.W., Rodriguez Traverso J.M., Quantitative genetics of Eucalyptus globulus: affinities of landrace and native stand localities, Silvae Genet. 50 (2001) 5-6.

[23] Lopez G.A., Potts B.M., Dutkowski G.W., Apiolaza L.A., Gelid P., Genetic variation and inter-trait correlations in Eucalyptus globulus base population trials in Argentina, For. Genet. 9 (2002) 223-237.

[24] Loveless M.D., Hamrick J.L., Ecological determinants of genetic structure in plant populations, Annu. Rev. Ecol. Syst. 15 (1984) $65-95$.

[25] McKinnon G.E., Vaillancourt R.E., Tilyard P., Potts B.M., Maternal inheritance of the chloroplast genome in Eucalyptus globulus and interspecific hybrids, Genome 44 (2001) 831-835.

[26] McKinnon G.E., Vaillancourt R.E., Steane D.A., Potts B.M., The rare silver gum, Eucalyptus cordata, is leaving its trace in the organellar gene pool of Eucalyptus globulus, Mol. Ecol. 13 (2004) 3751-3762.

[27] Moran G.F., Patterns of genetic diversity in Australian tree species, New For. 6 (1992) 49-66.

[28] Moran G.F., Bell J.C., The origin and genetic diversity of Pinus radiata in Australia, Theor. Appl. Genet. 73 (1987) 616-622.
[29] Moran G.F., Butcher P.A., Glaubitz J.C., Application of genetic markers in the domestication, conversation and utilisation of genetic resources of Australasian tree species, Aust. J. Bot. 48 (2000) $313-320$.

[30] Nesbitt K.A., Potts B.M., Vaillancourt R.E., West A.K., Reid J.B., Partitioning and distribution of RAPD variation in a forest tree species, Eucalyptus globulus (Myrtaceae), Heredity 74 (1995) 628637.

[31] Orme R.K., Eucalyptus globulus provenances, in: Proceedings of the Third World Consultation on Forest Tree Breeding, CSIRO, Canberra, Australia 1977, pp. 207-222.

[32] Potts B.M., Vaillancourt R.E., Jordan G., Dutkowski G., Silva J.C., McKinnon G.E., Steane D.A., Volker P., Lopez G., Apiolaza L., Li Y., Marques C.M., Borralho N., Exploration of the Eucalyptus globulus gene pool, in: Barralho N.M.G., Pereira J.S., Marques C., Coutinho J., Madeira M., Tomë M. (Eds) Eucalyptus in a changing world, Proceedings IUFRO Conference, Aveiro, Portugal, 1115 October 2004.

[33] Pritchard J.K., Stephens M., Donnelly P., Inference of population structure using multilocus genotype data, Genetics 155 (2000) 945959.

[34] Richardson T., Thomas, Mackenzie R.C.M., Lee J.R., Kent J., Carson S.D., Effects of domestication on genetic diversity in Pinus radiata, in: Proceedings Plant and Animal Genome V Conference, San Diego California, 1997.

[35] Soto A., Sánchez N., Astorga R., Alia R., Geographic structure of Eucalyptus globulus ssp. globulus populations according to chloroplast DNA, in: Barralho N.M.G., Pereira J.S., Marques C., Coutinho J., Madeira M., Tomë M. (Eds.), Eucalyptus in a changing world, Proceedings IUFRO Conference, Aveiro, Portugal, 11-15 October 2004.

[36] Steane D.A., Byrne M., Vaillancourt R.E., Potts B.M., Chloroplast DNA polymorphism signals complex interspecific interactions in Eucalyptus (Myrtaceae), Aust. Syst. Bot. 11 (1998) 25-40.

[37] Steane D.A., Vaillancourt R.E., Russell J., Powell W., Marshall D., Potts B.M., Development and characterisation of microsatellite loci in Eucalyptus globulus (Myrtaceae), Silvae Genet. 50 (2001) 89-91.

[38] Steane D.A., Conod N., Jones R.C., Vaillancourt R.E., Potts B.M., A comparative analysis of population structure of Eucalyptus globulus (Myrtaceae) using microsatellite markers and quantitative traits, Tree Genetics Genomes 2 (2005) 30-38.

[39] Yeh F.C., Yang R.C., Boyle T.J., Ye Z.H., Mao J.X., POPGENE, the user friendly shareware for population genetic analysis, Molecular Biology and Biotechnology Centre, University of Alberta, Edmonton, Canada, 1997.

[40] Zacharin R.F., Emigrant eucalypts: gum trees as exotics, Melbourne University Press, Melbourne, 1978.

[41] Zang D., Wang H., You Y., Performance and selection of a 4year Eucalyptus globulus seedling seed orchard in Yunnan, China, in: Potts B.M., Borralho N.M.G., Reid J.B., Cromer R.N., Tibbits W.N., Raymond C.A. (Eds.), Eucalypt plantations: Improving fibre yield and quality, Proceedings CRC-IUFRO Conference, Hobart, 19-24 February 1995, pp. 226-229.

[42] Zheng Y.Q., Ennos R.A., Genetic variability and structure of natural and domesticated populations of Caribbean pine (Pinus caribaea Morelet), Theor. Appl. Genet. (1999) 765-771. 